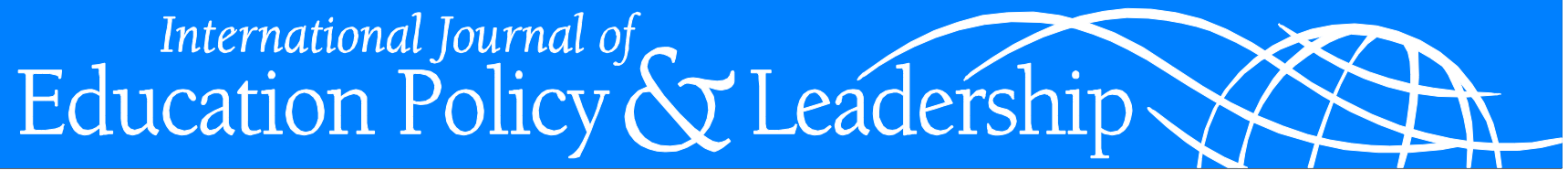

\title{
USE OF EPORTFOLIOS IN K-12 TEACHER HIRING IN NORTH CAROLINA: PERSPECTIVES OF SCHOOL PRINCIPALS
}

\author{
ABDOU NODOYE \\ Qatar University \\ ALBERT DiETER RITZHAUPT \\ University of Florida \\ MiCHELE A. PARKER \\ University of North Carolina, Wilmington
}

\begin{abstract}
This study explored the perceptions of principals involved in the hiring process of K-12 teachers in 11 counties in southeastern North Carolina. Forty-nine principals responded to a survey on ePortfolio use in the hiring process: the pros and cons, desirable artifacts, stage of use, preferred delivery method, and improvements that can increase their usage. We examined each of these questions and whether certain factors (prior use, technology skills, and years as a hiring agent) predict principals' ePortfolio use. Our findings suggest that ePortfolios provide improved and current information about teacher candidates that is easily accessible and organized. Collectively, this allows principals to assess teacher candidates' suitability for employment. Although there are problems associated with ePortfolio use during hiring, which are detailed below, the results suggest that principals most frequently use ePortfolios during the interview process, prefer delivery via a website address, and that prior use is the best predictor of future ePortfolio use.
\end{abstract}

Nodoye, A., Ritzhaupt, A. D., \& Parker, M. A. (2012). Use of ePortfolios in K-12 teacher hiring in North Carolina: Perspectives of School Principals. International Journal of Education Policy and Leadership 7(4). Retrieved from www.ijepl.org.

\section{Introduction}

The use of ePortfolios in teacher preparation has gained significant momentum since its early adoption in the mid 1990s (Lorenzo, Ittelson, 2005; Strudler \& Wetzel, 2005). The literature has identified three categories of ePortfolios (Lockledge \& Weinmann, 2001; Painter \& Wetzel, 2005; Ritzhaupt, Singh, Seyferth \& Dedrick, 2008; Wolf \& Dietz, 1997). According to Wolf and Dietz (1998), there is the (1) learning portfolio aimed at facilitating student learning, (2) the assessment portfolio mainly used for assessing and evaluating students' competencies, and (3) the employment portfolio designed to showcase a candidate's competencies for a position. These elements can be found and intentionally designed in the same ePortfolio. Though this widespread use of ePortfolio has gen- erated significant research, most studies have focused on learning and assessment (Foley, 2008; Ritzhaupt, Ndoye, \& Parker, 2010; Salzman, Denner, \& Harris, 2002). Whereas ePortfolios are being widely used in teacher preparation programs, there are still questions raised about whether ePortfolios are meeting the needs of all stakeholders (Pecheone, Pigg, Chung, \& Souviney, 2005; Ritzhaupt, Ndoye, \& Parker, 2010; Strawhecker, Messersmith, \& Balcom, 2007). This study examined school principals' use of ePortfolio in the hiring of $\mathrm{K}-12$ teachers in the state of North Carolina.

\section{Literature Review}

An ePortfolio can be defined as "a collection of evidence that is gathered together to show a per-

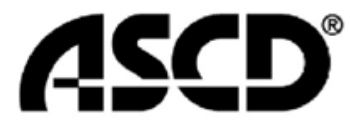

LEARN. TEACH. LEAD.
SEU SIMON FRASER UNIVERSITY THINKING OF THE WORLD

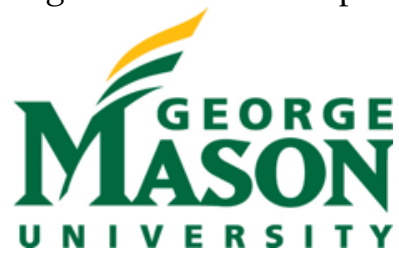


son's learning journey over time and to demonstrate their abilities" (Butler, 2006, p.2). In light of such definition, ePortfolios have taken a prominent role in assessing teacher candidates' competencies (Ntuli, Keengwe, \&Kyei-Blankson, 2009). As such, ePortfolios play a major role in showcasing and documenting evidence of competencies and skills expected of preservice teachers for many purposes, including employment (Ritzhaupt, Singh, Seyferth \& Dedrick, 2008; Strawhecker, Messersmith, \& Balcom, 2007; Theel \& Tallerico, 2004; Wolf \& Dietz, 1998).

The structure and nature of ePortfolios vary depending on its purpose; the different expectations of stakeholders pose an indefinite challenge. The reality of ePortfolios fulfilling multiple functions is questionable because there are times when one function may conflict with another. Researchers (Ritzhaupt, Singh, Seyferth \& Dedrick, 2008) have identified the many stakeholders and functions of ePortfolios and their different and competing needs. Whereas teacher candidates and teacher preparation programs seem to be the key stakeholders, it is obvious that the employment purpose cannot be fulfilled without an understanding of the needs and expectations of school administrators as hiring officials. Foley (2008) reported that "in addition to their utility as assessment tools, portfolios can support student advising and career preparation as well as professional and certification processes for practicing professionals" (p.1).

In their study of students and employers' perceptions of employment portfolios, Temple et al. (2003) indicated that students and career professionals both agreed that the ePortfolio was an effective way to address key selection criteria questions. Additionally, employers responding to the survey revealed experiencing a missing link between candidates' statements of what they can do and their abilities to actually do it, and that the ePortfolio can fill that void by showing evidence of teacher candidates' competencies through artifacts, video, and other digital means.

Given its interactive nature, an ePortfolio can provide varied and diversified means to evaluate factors that are not easy to assess via other sources such as a paper copy. In a study of factors considered most important in the hiring of new teachers, Cain-Caston (1999) found that evaluation of teaching performance and effective use of oral and written English as two of the top five factors listed as very critical in the hiring decisions. An ePortfo- lio can provide means of assessing these factors through diversified channels (audio, text, video, etc.) and ease of access to a preservice teacher's accomplishments and organizational and technological skills (Costantino \& Lorenzo, 2002). Further, Costantino and Lorenzo (2002) found that skills and characteristics such as enthusiasm for teaching, respect for children, and classroom management are also determinants in the hiring of new teachers. These skills and characteristics that are not content specific are easier to assess using an ePortfolio where preservice teachers can upload videos showing them interacting with students and display their practices (Wolf \& Dietz, 1998).

In a study of the role of portfolios in teacher hiring, Jacobson (1997) reported that "more school officials are requesting them, finding that they provide important insight into a teacher's individual talents and beliefs about education" (p. 12). The author surveyed more than 1,000 school administrators and superintendents around the country and found that more than half of the respondents to the survey "said they were more likely to request or accept a portfolio once the applicant had become a finalist for a teaching position" (p.1). These findings are similar to those of Anthony and Roe (1997), who reported from a national study of school districts' hiring practices that half of the school districts would request a portfolio when a candidate gets to the interview phase of the hiring process.

The studies above suggest that school hiring officials tend to request a portfolio at a given stage of the hiring process. Researchers (Painter $\&$ Wetzel, 2005; Strawhecker, Messersmith, \& Balcom, 2007; Temple, Allan, \& Temple, 2006; Wolf \& Diez, 1998) suggested guidelines and content for employment ePortfolios. These authors found that principals are more interested in ePortfolios that show video clips of preservice teachers interacting with students because this medium provides information that is difficult to obtain from other sources during the interview process.

Although ePortfolios may seem appropriate in assessing preservice teachers' skills, knowledge, and attitudes, scholars have cautioned about ways it should be used in order to encourage hiring officials' viewing of artifacts and to facilitate the decision-making process (Painter $\&$ Wetzel, 2005; Sivakumaran, Holland, \& Heyning, 2010). Hiring officials with busy schedules are more interested in reviewing ePortfolios with few and well-organized 
artifacts. Painter and Wetzel (2005) also report that the video of the teacher candidate interacting with students "makes the hiring portfolio more compelling" (p.1). Strawbecker, Messersmith, and Balcom (2007) contended that video is also an effective way to show a teacher candidate's ability and skills related to adapting and adjusting instruction, classroom management, and so on. Painter and Wetzel's (2005) study highlights the need to understand how hiring officials use ePortfolios during the employment process and the specific information they look for when viewing an ePortfolio.

Even though it is useful to understanding the type of information hiring officials look for in an ePortfolio, factors like previous ePortfolio use, technology skills, and years of experience as a hiring official can be critical in promoting ePortfolio use in hiring new teachers. Sivakumaran, Holland, and Heyning (2010) reported that hiring officials who view themselves as technology savvy tend to request an ePortfolio. Other researchers (Strawhecker, Messersmith, \& Balcom, 2007) have found that previous ePortfolio use, years as hiring officials, and technology skills are factors that can predict a principal's use of ePortfolio in the hiring process.

\section{Purpose}

This study attempts to add to what is known about ePortfolios in the hiring of $\mathrm{K}-12$ teachers by addressing the following research questions:

1. What are the pros and cons of using ePortfolios in the hiring process?

2. What do principals want to see in an ePortfolio?

3. When do principals use ePortfolios or Paper Portfolios in the hiring process?

4. What electronic delivery method is preferred?

5. What factors predict principals' likelihood of using ePortfolio?

6. What potential improvements would increase principals' use of ePortfolios in the hiring process?

\section{Method}

This study employed a mixed-method approach (Tashakkori \& Teddlie, 1998) involving both quantitative and qualitative procedures used concurrently and independently.

\section{Participants}

One hundred twelve principals from 11 counties in the southeastern United States were sent the survey and 49 responded, which is a response rate of 43.75 percent. The response rate is high for an online survey; prior research suggests that average online response rates fall somewhere within the range of 24-39 percent (Cook, Heath, \& Thompson, 2000; Hamilton, 2009; Kaplowitz, Hadlock, \& Levine, 2004; Sheehan, 2001).

Seventy-eight percent of the participants were over age 40 and have been serving as a hiring official for an average of 9.20 ( $S D=5.70)$ years. Fiftyone percent of the participants were principals at elementary schools, 24 percent at middle schools, and the remaining in high schools. These schools had an average of 695 (SD=360.44) students with 50 percent in rural, 38 percent in suburban, and 12 percent in urban regions. These schools had an average of 48.89 percent ( $S D=18.82)$ of students on free and reduced lunch programs. Respondents' level of technology usage vary across many different forms as indicated in the table below. Table 1 illustrates the technology use of these principals on a regular basis.

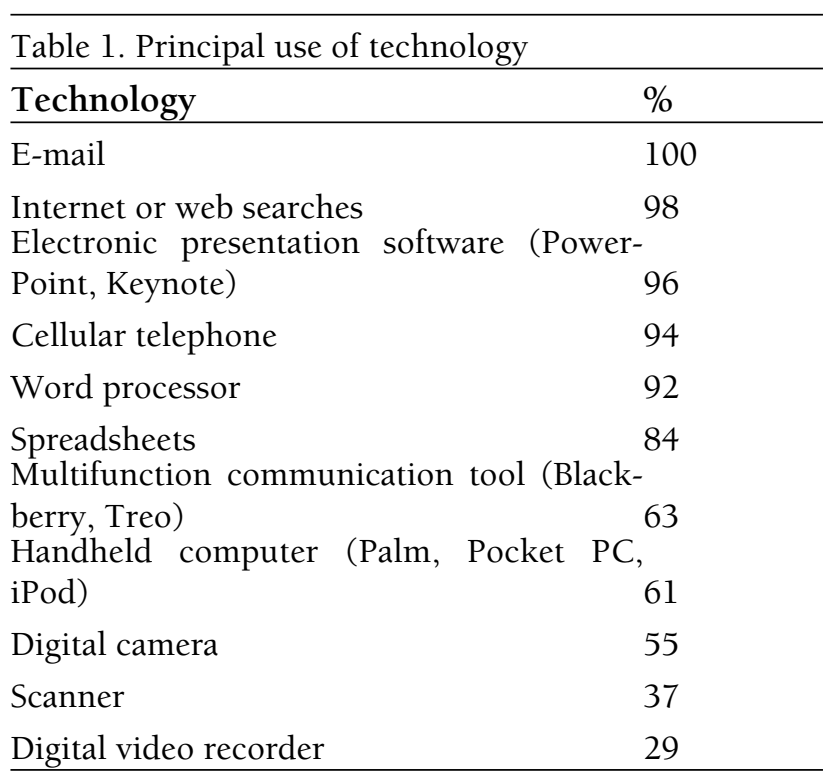




\section{Instrument}

The 23-item survey used in this research was adopted from a previous study and slightly tailored to meet the needs of this research program (Strawhecker, Messersmith, \& Balcom, 2007). The survey had previously been validated for content and was deemed appropriate for the target audience (principals) by administration through a pilot survey. The survey included a combination of dichotomous items, Likert scales (strongly disagree, disagree, neutral, agree, strongly agree), semantic differential scales (least preferred $=1$ to most preferred $=4$ ), and free-form response items. The Likert scale items had a Cronbach's alpha of .89. The dichotomous items had a K-R 20 of 87.

\section{Procedures}

The instrument was made accessible in a webbased format using SelectSurvey@. To encourage participation, respondents could optionally provide their name and e-mail address to be entered in a raffle to win a flip video camera. The researchers sent a hyperlink to the instrument in an e-mail encouraging participants to respond to the survey.

\section{Data Analysis}

Quantitative analyses of the data included descriptive, internal consistency reliability analysis, and predictive forward multiple regression analysis. Multiple regression analysis was conducted to examine the predictors of ePortfolio usage. All quantitative analyses were conducted using SPSS $\odot$ version 16 and $\alpha=.05$. Two open-ended survey items were included in the survey for the purpose of gaining further insight into the pros and cons of ePortfolio usage. The data were analyzed using a constant comparative analysis (Glaser, 1965; Glaser, 1967).

\section{Results}

\section{Pros and Cons of ePortfolios}

Principals were provided the opportunity to provide free-form responses on the pros and cons of ePortfolios. Several central themes, for pros, included improved current information about candidates, easily accessible and organized candidate information, evidence of effort and ability in arti- facts, and better judgment. One respondent summarized these themes well by saying, "I was able to see their products, organizational ability, and quality of their work."

The primary themes that emerged from the cons were the time-consuming and burdensome process of evaluating ePortfolios, the lack of standardization, lack of real connection to classroom practice, and that only the best work is shown. One respondent said that the ePortfolios were "cumbersome to go through" and another said that they are "just one element and [don't] tell you if they can teach."

\section{Desired ePortfolio Artifacts}

A candidate's ePortfolio can contain numerous artifacts that are helpful to the selection process. Table 2 illustrates a variety of artifacts and the associated response frequency for principals that selected that artifact. As can be gleaned, a candidate's resume was the most desired artifact (98 percent),

Table 2. Desired ePortfolio artifacts

\begin{tabular}{lc}
\hline Artifact & $\%$ \\
\hline Candidate's resume & 98 \\
References & 88 \\
Letters of recommendation & 88 \\
Reflection on teaching experiences & 84 \\
Samples of instruments used for assessment & 80 \\
Sample lesson plans & 78 \\
Information about the candidate's previous & work \\
experience & 76 \\
Transcripts & 73
\end{tabular}

Video clip showing the candidate teaching in a classroom setting $\quad 73$

Student teacher evaluations $\quad 73$

Candidate's teaching philosophy statement 63

Artifacts to document experience with ethnic and cultural diversity

Artifacts that document community service learning activities 45

Examples of candidate's work in college teaching methods classes 31

shortly followed by references and letters of recommendation (88 percent each). Also important was a candidate's reflection on teaching experiences, which are commonly included in ePortfo- 
lios. Surprisingly, principals were least interested in examples of a candidate's products from methods classes, which are also commonly included in ePortfolios.

\section{Use of Portfolios in Hiring}

Another central question is when principals use portfolios (either paper or electronic) in the hiring process. The results shown in Table 3 suggest that principals use portfolios most frequently during the interview process and second most frequently during the initial screening of candidates. Much less frequent was the use of a portfolio after the short list of candidates was determined and after the interview, but before hiring.

\begin{tabular}{lc}
\hline \multicolumn{2}{l}{ Table 3. Stages of portfolio use in hiring process } \\
\hline Stage & $\%$ \\
\hline During the interview process & 69 \\
Initial screening & 44 \\
After the short list of candidates was & deter- \\
mined & 25 \\
After the interview but before hiring & 14 \\
\hline
\end{tabular}

\section{Preferred Delivery Method}

ePortfolios can be viewed using a variety of media. One important question is what is the preferred delivery method of the principals? Our results, shown in Table 4 (next page), illustrate that these principals primarily wish to view a candidate's ePortfolio via a website address $(\mathrm{M}=3.42$; $\mathrm{SD}=1.04)$. Comparatively, $\mathrm{CDs}(\mathrm{M}=2.52 ; \mathrm{SD}=0.97)$ and DVDs $(\mathrm{M}=2.24 ; \mathrm{SD}=0.89)$ were rated lower on the scale of one to four, where one is the least preferred and four is the most preferred. Most ePortfolio systems (e.g., Chalk \& Wire, Tasktream) include the capacity for the ePortfolio creator to provide a secure hyperlink to the ePortfolio contents. Users can also burn the contents of their ePortfolio to a CD or DVD for dissemination.

\section{Factors Predicting ePortfolio Usage}

Next, we investigated whether or not future ePortfolio use in the hiring process can be predicted from relevant variables such as previous ePortfolio use, years as a hiring official, etc. Our regression equation used in Table 5 (next page) includes previous ePortfolio use, previous paper portfolio use, years as the hiring official, and self-reported tech- nology skill level as predictors for future ePortfolio use. The R-Square for the model is .318, which means approximately 32 percent of the variability is explained in the model. Previous ePortfolio use was the only statistically significant predictor in the model. Results of this analysis suggest that the best predictor of future ePortfolio use is prior ePortfolio usage.

\section{Improvements to ePortfolio Process}

Finally, we discerned what factors may contribute to increasing principals' willingness to use ePortfolios in the hiring process. These results are shown in Table 6 (next page). The most important factor was a standard ePortfolio format for candidates to follow. A standard rubric for principals to use in evaluating ePortfolios was also important and was followed by technology training to assess them.

\section{Discussion}

Interpretation of the results must be viewed within the limitations of this research. Although the response rate was high based on previous research (Cook, Heath, \& Thompson, 2000; Hamilton, 2009; Sheehan, 2001), the limited sample size confines the generalizability of the results. The relatively small sample size could be because study respondents have administrative responsibilities during most of the workday and would therefore have more difficulties taking time to respond to a survey (Marshall \& Rossman, 1999). Additionally, generalizability of the results is limited because the data was collected from one region within North Carolina. In light of these limitations, this research has resulted in several interesting findings.

The results indicate that principals use ePortfolios during some phases of the hiring process but not the entire process. According to these results, principals use ePortfolios in the earlier stages (initial screening) so they can screen applicants and during the interview process itself. ePortfolios are easily accessible and have the potential to organize up-to-date candidate information while providing evidence of candidate's ability through the selection of artifacts. These results corroborate the findings of previous research (Strawhecker, Messersmith, \& Balcom, 2007), particularly in relation to the organization of a candidate's work.

In terms of cons, our findings suggest that ePortfolios are time-consuming and cumbersome 
Table 4. Preferred delivery method of ePortfolios.

\begin{tabular}{lcccccc}
\hline \multicolumn{1}{c}{ Delivery method } & $\mathbf{1}$ & $\mathbf{2}$ & 3 & 4 & $\mathrm{M}$ & SD \\
\hline $\begin{array}{l}\text { Website address to view in a computer } \\
\text { browser }\end{array}$ & $12.5 \%$ & $2.08 \%$ & $16.67 \%$ & $68.75 \%$ & 3.42 & 1.04 \\
$\begin{array}{l}\text { CD to play on my computer } \\
\text { DVD to play on my computer or televi- }\end{array}$ & $21.74 \%$ & $17.39 \%$ & $47.83 \%$ & $13.04 \%$ & 2.52 & 0.97 \\
$\begin{array}{l}\text { sion } \\
\text { Other }\end{array}$ & $66.67 \%$ & $8.33 \%$ & $0 \%$ & $25 \%$ & 1.83 & 1.34 \\
\hline
\end{tabular}

to evaluate, lack standardization and connection to classroom practice, and display a candidate's best work (as opposed to development or weaknesses). This also corresponds with the results of prior studies (Theel \& Tallerico, 2004 ; Strawhecker, Messersmith, \& Balcom, 2007). For instance, principals in Theel and Tallerico's study "expressed strong preferences for increased standardization of portfolio reviews" (p.28). The authors also highlight the lack of real connection to classroom practice through "skepticism about the relationship between portfolio documents and candidates' actual abilities to teach" (p.29).

Table 5. Multiple regression analysis with future ePortfolio use as dependent variable

\begin{tabular}{lccc}
\hline \multicolumn{1}{c}{$\begin{array}{c}\text { Independent } \\
\text { variable }\end{array}$} & $\begin{array}{c}\text { Standardized } \\
\text { Weight (Beta) }\end{array}$ & $\mathrm{t}$ & $\mathrm{p}$ \\
$\begin{array}{l}\text { Previous ePortfolio } \\
\text { use }\end{array}$ & 0.46 & 3.14 & $.003^{*}$ \\
$\begin{array}{l}\text { Previous paper } \\
\text { portfolio use }\end{array}$ & 0.20 & 1.40 & .17 \\
$\begin{array}{l}\text { Self-reported tech- } \\
\text { nology skill level }\end{array}$ & 0.12 & 0.91 & .37 \\
$\begin{array}{l}\text { Years as the hiring } \\
\text { official }\end{array}$ & -0.01 & -0.09 & .93 \\
\hline *denotes statistical significance & &
\end{tabular}

To address the problem of "best work," Campbell, Cignetti,Melenyzer, Nettles, and Wyman, (2007) advocate the inclusion of artifacts that address teacher candidate's weaknesses. These include peer critiques, evaluations, letters to (or from) parents, problem-solving logs, selfassessment instruments, and descriptions of work or volunteer experiences. An anticipated criticism is that these documents can be tinted to favor the candidates being reviewed for employment. How- ever, these artifacts would be authentic representations from multiple sources that can be used to triangulate information about the teacher candidate under consideration. This would provide the principal with meaningful information that could be used during induction and professional development once a teacher is employed.

In terms of desired ePortfolio artifacts, our findings, as suggested by previous research (Sivakumaran, et. al, 2010), indicate that a candidate's resume, references, letters of recommendation, reflections on teaching practices, and samples of instruments used for assessments are the most desired ePortfolio artifacts. Whereas previous research (Wolf \& Dietz, 1998) indicated video clips as one of the of the most preferred types of artifacts, respondents of this study seem to indicate a different perspective as they rank video clip ninth out of 15 given their desired type of artifacts. Such finding could be a reflection of respondents not regularly using video clips related technology (digital camera 55 percent, digital video recorder 29 percent; see table 1).

Table 6. Principals' Responses to Options for Improving ePortfolio Use A standard format for candidates to follow 94

A standard procedure or rubric for assessing ePortfolios 45

Training on the technology needed to assess ePortfolios

The well-conceived and thorough documentation that students provide in their ePortfolios as part of the collegiate experience may need to be significantly reduced for employment purposes, especially if the main components correspond with a regular job search (resume, letters of recommen- 
dation, and references). This can foster dissatisfaction among students who realize that potential employers are not recognizing their time and hard work crafting their ePortfolios (Parker, Ndoye, \& Ritzhaupt, n.d.), and equal dissatisfaction among hiring officials who are presented with detailed ePortfolios but want less information.

The least important artifacts included the ones used to document experience with ethnic and cultural diversity (53 percent), artifacts that document community service learning activities (45 percent), and examples of a candidate's work in college teaching methods classes (31 percent). These are informative findings because work products from teaching methods classes are commonly included in ePortfolio templates. This mirrors other incongruence discussed in the literature; for example, Barrett (1999), highly recommends that ePortfolios be organized by professional teaching standards, while Painter and Wetzel (2005) stated that hiring officials were more interested in organization by $\mathrm{K}-12$ standards related to student achievement.

Whereas most ePortfolio systems have the capacity for templates (Barrett, 1999), the lack of standardization in the inclusion of artifacts across various education programs and schools remains a challenge (Strudler \& Wetzel, 2005). As an aside, reflections and students assessments may be consistent elements, which is why they are primarily reviewed in comparison to other artifacts. The use of various ePortfolio systems to review teacher candidates suggests difficulty for employers who are uncomfortable with technology, decreasing usability and assessment (Strawhecker, Messersmith, \& Balcom, 2007).

A surprising finding of this study is the fact that experience with ethnic and cultural diversity and artifacts that document community service learning activities were not rated as highly desired by principals in this study. This is in contrast with the widespread discussion currently happening in teacher preparation programs on ways to provide teacher candidates with diversity and communityrelated experiences to help them address the needs of diverse learners (Maude, 2010; Nagda \& Lopez, 2003; Onore \& Gildin, 2010, Todd, 2007). One explanation of this finding could be that principals feel like an ePortfolio may not the best place to assess skills and competencies related to diversity and community service.
Another plausible explanation is that the artifacts that are reviewed less frequently may be less crucial when searching for a position. For instance, a teacher's lack of experience with classroom diversity may be a result of internship placement, rather than the result of a candidate's dispositions or ability to work with target audiences. Imig and Imig (2006) use data from the National Center of Educational Statistics to demonstrate that novice teachers are more likely to be employed in diverse settings (those with large percentages of free or reduced-price lunch recipients, minorities, limited English proficiency students). Therefore, the teacher candidates are likely to gain this experience once they are employed. Similarly, community involvement is a school-level responsibility and has been documented as a leadershipdriven initiative that is a key component in school turnaround (Duke, 2004).

Yet, as illustrated by Strawhecker, Messersmith, and Balcom (2007), this information must be placed in context. ePortfolios typically contain multiple documents and evidences such as those listed on the survey employed in this study (Strudler \& Wetzel, 2005; Campbell, Cignetti, Melenyzer, Nettles, \& Wyman 2007). This variation increases when reflection (or reflection and feedback) are included with each artifact (Barrett \& Knezek, 2003). With an overabundance of information, principals must select which sources to review carefully and quickly. Because colleges and schools of education make the decisions about what to include in an ePortfolio and this varies across programs (Strudler \& Wetzel, 2005), teacher educators should reflect on these findings of this study to assure that the appropriate information is included in a preservice teacher's ePortfolio. Although principals serve as the main hiring officials, superintendents, experienced teachers, and school board members may also review teacher candidates' ePortfolios(Campbell, Cignetti, Melenyzer, Nettles, \& Wyman 2007).

The findings suggest that ePortfolios, in this setting, are most frequently used during the interview process, followed by after the initial screening of candidates. This indicates that ePortfolio is one aspect of the interview process. Hence, ePortfolios need to be designed as one component of a system and developed with targeted evidences that provide meaningful yet unduplicated information. Our findings confirm, as in previous research (Strawhecker, Messersmith, \& Balcom, 2007), that 
principals prefer a website address as the delivery method for a candidate's ePortfolio as opposed to a CD or DVD. Our results suggest the best predictor of future ePortfolio use is prior use of ePortfolios.

\section{Implications}

The findings reported above have policy and leadership implications for teacher education programs. One of the first aspects of the policy implications involves the development and establishment of shared processes and procedures between potential employers and teacher education programs with the creation and maintenance of a standard format for ePortfolios across teacher candidates. This standard format, which can be localized, can assist principals with busy schedules by providing an ordinary view of a candidate's ePortfolio, thus streamlining the amount of time a principal will spend searching for specific information about a candidate. Regular conversations and collaboration between teacher educators and K-12 hiring officials could help facilitate the success of such a policy.

The results have leadership implications; teacher education programs need to make sure teacher candidates are prepared to take leadership roles in developing and maintaining portfolios that really show their abilities to manage their competencies. Teacher education programs need to anticipate such roles by providing their candidates with the necessary technological skills that would allow them to use that medium to its greatest potential and better match their skills with employers' expectations. Leadership implications will also involve developing students' creativity, ownership, and self-directed learning to allow teacher candidates to better organize the ePortfolio and take the lead in developing better connections among skills to showcase their competencies.

Leadership implications of these results also require providing school leaders with the necessary skills to effectively navigate an ePortfolio in an acceptable timeframe. Clearly, if principals do not have the necessary skills to traverse an ePortfolio, they will not use it effectively and efficiently to facilitate the hiring process. Teacher education programs could opt to offer workshops or online training for principals in the surrounding schools to facilitate the process.

Another important implication to teacher education programs relates to the type of information included within a typical ePortfolio. Our findings clearly suggest that a candidate's resume, references, letters of recommendation, reflections of teaching experiences, and sample instruments used for assessment are valuable artifacts to the usual principal in evaluating a teacher candidate. Effort should be placed on designing an ePortfolio across teacher candidates that includes, at minimum, this vital information. As such, administrators and faculty should encourage teacher candidates to be particularly selective about including artifacts viewed as pertinent by principals in this study in an employment ePortfolio.

A broader policy and leadership concern is whether ePortfolio contents should be viewable to other stakeholders in an education system (such as parents, students, etc.). What is the anticipated level of privacy for an ePortfolio? How accessible will the artifacts be to other stakeholders? In an age of social media, ePortfolios might be perceived as yet another social medium. However, we believe teacher education programs, preservice and inservice teachers, and principals should be mindful of who is viewing, commenting, and using ePortfolios in general. To address this, many ePortfolio systems (e.g., Chalk \& Wire, Taskstream) have secured hyperlinks that limit the number of stakeholders that can use a teacher's ePortfolio. Our research does not address this major concern, but we believe this is an important consideration for future research.

\section{Conclusion}

Results of this study provided insights on ways and the purposes for which principals use ePortfolios in the hiring of teacher candidates, and may therefore help preservice teachers tailor the design, content, and organization of ePortfolios to make it more compatible to employers' needs. These results, though geographically circumscribed (only the state of North Carolina), can provide a foundation for teacher education programs. Administrators and teacher education programs should use these results to start and reinforce conversations in order to develop and promote a system's approach to support the development and expansion of ePortfolios. An approach that takes into account the needs of teacher education programs, teacher candidates, and the potential employers will only make ePortfolios more sustainable and meaningful. 


\section{References}

Anthony, R., \& Roe, G. (1997). Selecting teachers for tomorrow's classrooms. Technical report. Madison, WI: Educational Placement Consortium.

Barrett, H. (1999). Electronic teaching portfolios. Retrieved from http://electronicportfolios.org/portfolios/site99. html

Barrett, H. \& Knezek, D. (2003). e-Portfolios: Issues in assessment, accountability and preservice teacher preparation. Retrieved from http://www.electronicportfolios.com/portfolios/ AERA2003.pdf

Campbell, D. M., Cignetti, P. B., Melenyzer, B. J., Nettles, D. H., Wyman Jr., R. M. (2007). How to develop a professional portfolio: A manual for teachers. Boston: Pearson.

Cian-Caston, M. (1999). A survey of opinions of North Carolina school administrators regarding factors considered most important in hiring teachers for their first teaching position. Journal of Instructional Psychology, 26 (2), 69-73

Cook, C., Heath, F., \& Thompson, R. L. (2000). A meta-analysis of response rates in web- or Internet-based surveys. Educational and Psychological Measurement, 60(6), 821-836.

Costantino, P., \& De Lorenzo, M. (2002). Electronic portfolios: An option. In Developing a Professional Teaching Portfolio (pp. 47-55). Boston: Allyn and Bacon.

Duke, D. (2004). The challenges of educational change. Boston: Pearson.

Foley, A. (2008). Using ePortfolios to demonstrate growth and assess learning. White Paper. Retrieved on June 23, 2010 from:

http://www.adobe.com/education/pdf/acrobat-e portfolios-wp.pdf

Glaser, B. G. (1965). The constant comparative method of qualitative analysis. Social Problems, 12(4), 436-445.

Glaser, B. G. (1967). The constant comparative method of qualitative analysis. In B. Glaser $\&$ A. Strauss (Eds.), The discovery of grounded theory: Strategies for qualitative research (pp. 101116). Chicago: Aldine.

Imig, D., \& Imig, S. R. (2006). What do beginning teachers need to know? An essay. Journal of Teacher Education, 57(3), 286-291.
Jacobson, L. (1997). Portfolios playing increasing role in teacher hiring. Education Week, 16(23), $12-14$.

Hamilton, M.B. (2009). Online survey response rate and times: Background and guidance for industry. Retrieved from:

http://www.supersurvey.com/papers/supersurve y_white_paper_response_rates.pdf_on May 12, 2011

Kaplowitz, M.D., Hadlock, T.D., \& Levine, R. (2004). A comparison of web and mail survey response rates. Public Opinion Quarterly, 68(1), 94-101

Lockledge, J.C., \& Weinmann, J.A. (2001). Knowledge management for multi assessment portfolios. European Journal of Engineering Education, 26(3), 311-321.

Marshall, C. \& Rossman, G. B. (1999). Designing qualitative research. Thousand Oaks, CA: Sage.

Gurin, P.; Nagda, A. A.; Lopez, G. E. (2004). The benefits of diversity education for democratic citizenship. Journal of Social Issues, 60(1), 1734

Lorenzo, G., \& Ittelson, J. (2005). An overview of Eportfolios. Educause Learning Initiative.

Retrieved from http://net.educause.edu/ir/library/pdf/ELI3001.p df on May 12, 2011.

Maude, S. P., Catlett, C., Moore, S., Sanchez, S. Y.; Thorp, E. K. \& Corso, R. (2010). Infusing diversity constructs in preservice teacher preparation: The impact of a systematic faculty development strategy. Infants and Young Children, 23(2), 103-121.

Ntuli, E., Keengwe, J., \&Kyei-Blankson, L. (2009). Electronic Portfolios in Teacher Education: A Case Study of Early Childhood Teacher Candidates. Early Childhood Education Journal, 37(2), 121-126. Retrieved from ERIC database.

Onore, C. \& Gildin, B. (2010). Preparing urban teachers as public professionals through a university-community partnership. Teacher Education Quarterly, 37(3), 27-44.

Painter, S., \& Wetzel, K. (2005). School administrators' perceptions of the use of electronic portfolios in $\mathrm{K}-8$ teacher hiring. Journal of Computing in Teacher Education, 22(1), 23-29.

Parker, Ndoye, \& Ritzhaupt. (Under Review). Qualitative analysis of ePortfolios in teacher education: Implications for successful integration. 
Pecheone, R. L, Pigg, M. J., Chung, R. R., and Souviney, R. J. (2005). Performance assessment and electronic portfolios: Their effect on teacher learning and education, The Clearing House, 78(4), 164-176.

Ritzhaupt, A., Ndoye, A. \& Parker, M. (2010). Validation of the Electronic Portfolio Student Perspective Instrument (EPSPI): Conditions under a different integration initiative. Journal of Digital Learning in Teacher Education, 26(3), 111-119.

Salzman, S., Denner, P., \& Harris, L. (2002). Teaching education outcomes measures: Special study survey. Paper presented at the Annual Meeting of the American Association of Colleges of Teacher Education, New York, NY.

Sheehan, K. (2001). E-mail survey response rates: A review. Journal of Computer-Mediated Communication, 6(2), Retrieved on May 19, 2009 from:

http://jcmc.indiana.edu/vol6/issue2/sheehan.ht $\mathrm{ml}$

Sivakumaran, T.; Holland, G.; Heyning, K. (2010). Hiring agents' expectations for new teacher portfolios. National forum of teacher education journal, 20(3),
Strawhecker, J., Messersmith, K., \& Balcom, A. (2007). The role of electronic portfolios in the hiring of K-12 teachers. Journal of Computing in Teacher Education, 24(2), 65 - 71. Strudler, N. $\&$ Wetzel, K. (2005). The diffusion of electronic portfolios in teacher education: Issues of initiation and implementation. Journal of Research on Technology in Education, 37(4), 411 433.

Tashakkori, A. \& Teddlie, C. (1998). Mixed Methodology: Combining Qualitative and Quantitative Approaches. Thousand Oaks, California: Sage.

Temple, V., Allan, G., \& Temple, B. (2003). Employers' and students' perceptions of electronic employment portfolios. Available at: http://www.aare.au/03pap/tem03523.pdf

Todd, J. (2007). Addressing diversity in US teacher preparation programs: A survey of elementary and secondary programs' priorities and challenges from across the United States of America. Teaching and Teacher Education: An International Journal of Research and Studies, 23(8), 1258-1271.

Wolf, K., \& Dietz, M. (1998). Teaching portfolios: Purposes and possibilities. Teacher Education Quarterly, 25(1), 9-22.

IJEPL is a joint publication of the Association for Supervision and Curriculum Development, the Faculty of Education at Simon Fraser University, and the College of Education and Human Development at George Mason University. By virtue of their appearance in this open access journal, articles are free to use, with proper attribution, in educational and other noncommercial settings 90 days after initial publication. Copyright for articles published in IJEPL is retained by the authors. More information is available on the IJEPL Web site: http://www.ijepl.org 